\title{
Postnatal Effect Of Acrylamide On Rat Renal Cortex And The Protective Effect Of Ginger (Zingiber Officinale Roscoe)
}

\section{Original Article}

\author{
Rania Said Moawad, Eman Ramadan Abd El Fattah, Rania Saad Ramadan
}

Anatomy and Embryology Department, Faculty of Medicine, Zagazig University

\begin{abstract}
Background: Acrylamide is toxic both in experimental animals and in humans. It is proved to be carcinogenic in rodents and considered by The International Agency for Research on Cancer as a probable human carcinogen. Medicinal plants have significant antioxidant properties. Ginger had the highest antioxidant activity among these plants.

Aim of the work: To detect the histopathological effects of acrylamide on the kidneys in postnatal rats and to determine the possible protective effect of Ginger (Zingiber officinale Roscoe) as an antioxidant.

Methods: The experimental pregnant rats were randomly divided into 3 groups:

Group 1 (control group): these rats were preserved under normal condition of diet and water. Group 2 (acrylamide-treated group): acrylamide was orally administered to non-anesthetized rats by gastric intubation at a dose of $10 \mathrm{mg} / \mathrm{kg} / \mathrm{day}$. Group 3 (ginger-protected group): animals of this group were given the same dose of acrylamide as in group 2 followed by 1 $\mathrm{ml}$ of final aqueous extract of ginger $(24 \mathrm{mg} / \mathrm{ml})$ three times weekly. All the doses were administered from the 7 th day of gestation and continued up to 21 days after delivery. Postnatal rats at the 2 nd and 21 st days were selected from each group and were scarified. Their kidneys were carefully dissected, removed and fixed in $10 \%$ formalin for histopathological and immunohistochemical examinations.

Results: Maternal acrylamide administration disturbed the development of the renal cortex of the offsprings. Histological examination of acrylamide-treated, 2-day-old rats revealed degenerated glomeruli with lack of capillary tufts, disarrangement of podocytes and thickening of the parietal layers of Bowman's capsules. Moreover, the damage was evident in the primitive tubules. Examination of acrylamide-treated, 21-day-old rats showed congested glomerular capillaries, mesangial hypercellularity, vacuolations and darkly stained nuclei of the renal tubular epithelium, and extensive interstitial cellular infiltration and hemorrhage. Statistically, acrylamide-treated groups at both ages showed a highly significant decrease in the mean glomerular count, and the mean thickness of the cortex and the medulla as compared to their control groups. Moreover, the area percentage of renal NF-k $\beta$ protein expression showed a significant increase with acrylamide treatment. Ginger administration effectively restored most of the acrylamide-induced renal cortical damage.

Conclusion: ginger administration effectively restored most of the acrylamide-induced renal cortical damage, suggesting that ginger supplement can play a protective role against acrylamide deleterious effects.
\end{abstract}

Received: 12 June 2018, Accepted: 29 September 2018

Key Words: Acrylamide, ginger, kidney, rat.

Corresponding Author: Eman Ramadan Abd El Fattah, Anatomy and Embryology Department, Faculty of Medicine, Zagazig University, Egypt, Tel.: +20 1022242343, E-mail: emanramadan898@yahoo.com

ISSN: 1110-0559, Vol. 42, No. 1

\section{INTRODUCTION}

Acrylamide is white crystalline, odorless highly water soluble. These properties promote its absorption and distribution all over the body ${ }^{[1,2]}$.

It is present in a high concentration in plants such as potatoes, rice, carrots, Chinese cabbage, lettuce, parsley, onions, spinach, and also in sugar and olives ${ }^{[3]}$.

It is also detected in tobacco and cigarette smoke. In industry, they are used in synthesis of grooming products as lotions, cosmetics and deodorants ${ }^{[2,4]}$.

Acrylamide is formed in foods cooked at high temperatures (higher than $200^{\circ} \mathrm{C}$ ). Its concentration in fried potato (chips) ranged from
376 to $2348 \mathrm{microg} / \mathrm{kg}^{[5,6]}$. Its toxic effect is attributed to heat-induced reactions between the amino group of the free amino acid asparagine and carbonyl groups of glucose and fructose present in potatoes, cereals, and other plantderived foods ${ }^{[7,8]}$.

Acrylamide toxicity occurs if it is bio-transformed into a more potent and highly reactive molecule induced mainly by cytochrome P450 2E1 (CYP2E1). The oxidative biotransformation of acrylamide results in formation of metabolite; glycidamide, which is more reactive towards proteins, including hemoglobin and DNA, than acrylamide itself $^{[9,10]}$.

Acrylamide toxicity on various body organs has been reported previously. These include neurotoxicity and 
reproductive system toxicity ${ }^{[11,12]}$. The International Agency for Research on Cancer classified acrylamide as a probable human carcinogen on the basis of its carcinogenicity in rodents $^{[13,14]}$.

Acrylamide has a significant binding capacity to liver, brain, kidney and erythrocyte ${ }^{[15,16]}$. It crosses the placenta leading to direct prenatal and postnatal anomalies ${ }^{[14]}$.

Medicinal plants have a role in pharmacology and medicine for the last few decades. It has been estimated that about $80 \%$ of the world population depends on botanical preparations as medicine to meet their health needs. Ginger (Zingiber officinale Roscoe) is an example of botanicals which is gaining popularity amongst modern physicians and its underground rhizomes are the medicinally useful part. Many studies were carried out on ginger and its pungent constituents, fresh and dried rhizome ${ }^{[17]}$

One of the most popular uses of ginger is to relief the symptoms of nausea and vomiting associated with motion sickness, surgery and pregnancy. Ginger has antiplatelet, anti-oxidant, anti-cancer, anti-rhinoviral, antihepatotoxicity and anti-arthritic effects ${ }^{[18]}$.

Ginger contains the highest number of antioxidants. Gingerols are the most important components of ginger that have significant antioxidant properties. In addition, they have a high antioxidant activity as it contains vitamins such as $\mathrm{A}, \mathrm{B}, \mathrm{C}$ and $\mathrm{E}$ as well as flavonoids and glutathione ${ }^{[19]}$.

Therefore, this study was carried out to evaluate the postnatal histopathological and immunohistochemical effects of acrylamide on the rat renal cortex and to determine the possible protective effect of ginger as an antioxidant

\section{MATERIALS AND METHODS}

\section{Chemicals:}

Acrylamide (99\% pure) was purchased from Sigma Chemical Company (St Louis, MO, USA).

\section{Animals and Dosing Schedule:}

Twenty-one females and ten male Wistar rats (50-60 days old, 200-220 grams) were used in this study. They were obtained from the Animal House of Faculty of Medicine, Zagazig University. Rats were kept under hygienic conditions. Standard food and water ad-libitum were administrated. The male rats were used for fertilization of the female ones. Gestation was authenticated in the next morning by perception of the vaginal plug, and this time was designated as gestation day 0 . Female pregnant rats were randomly divided into 3 groups of 7 rats each:

Group 1 (control group): these rats were preserved under normal condition of diet and water.

Group 2 (acrylamide-treated group): acrylamide $(10 \mathrm{mg} / \mathrm{kg} /$ day) was dissolved in $10 \mathrm{ml}$ distilled water so each $1 \mathrm{ml}$ water contained $1 \mathrm{ml}$ acrylamide. Each rat was given $2 \mathrm{ml}$ distilled water contained $2 \mathrm{ml}$ acrylamide and orally administered to non-anesthetized pregnant rats by gastric intubation from the $7^{\text {th }}$ day of gestation and continued up to 21 days after delivery. The present dose was applied because the overdoses will reduce reproductive activity of mothers and cause paralysis

Group 3 (ginger-protected group): animals in this group were given the same dose of acrylamide given to animals of group 2 followed by $1 \mathrm{ml}$ of final aqueous extract of ginger three times weekly from the $7^{\text {th }}$ gestational day and continued up to 21 days after delivery. This dose of ginger was selected according to Sakr et al. ${ }^{[17]}$.

Ginger (Z. officinale Roscoe) rhizome was purchased from the local market at Zagazig, Egypt. One-kilogram fresh ginger rhizome was cleaned, washed under running tap water, cut into small pieces then air dried and powdered. $125 \mathrm{~g}$ of this powder were macerated in $1000 \mathrm{ml}$ of distilled water for $12 \mathrm{~h}$ at room temperature and were then filtered. The concentration of the extract was $24 \mathrm{mg} / \mathrm{ml}$ (this concentration is obtained after filtering the solution and separated the solid powder which weighted 101g from $125 \mathrm{~g}$ (the original weight) from the liquid solution which contained the remaining weight of the powder equal $24 \mathrm{~g}$ dissolved in proximally $1000 \mathrm{ml}$ water. So, the amount of ginger dissolved in water $0.024 \mathrm{~g} / \mathrm{ml}=24 \mathrm{mg} / \mathrm{ml}$ ). Each animal in the present study was given $1 \mathrm{ml}$ of the final aqueous extract orally.

Experiment was designed to study toxicity of acrylamide on kidney of rat offsprings at the 2nd and $21 \mathrm{st}$ postnatal days. 5 rats were selected from each group in the previous two ages $\left(2^{\text {nd }}\right.$ and $21^{\text {st }}$ postnatal days) where they were sacrificed. The kidneys were carefully dissected and removed. Their fatty covering connecting tissue were gently removed. All procedures used in this study were approved by the Ethical Committee of the Faculty of Medicine, Zagazig University, Egypt.

\section{Preparation of tissues for histopathological examination:}

Light microscopic (LM) study: kidneys were excised and fixed in $10 \%$ neutral buffered formalin; then processed to obtain paraffin blocks which were cut into sections of $5 \mu \mathrm{m}$ thickness, mounted on glass slides, deparaffinized in xylene and stained by: hematoxylin and eosin stain (H\&E) and immuno-histochemical stain for detection of NF-k $\beta$ using anti- NF-kBp65 antibodies were rabbit polyclonal NF-k $\beta$ p65 antibody (dilution 1:100; Santa Cruz Biotechnology, Santa Cruz, CA, USA) respectively. Sections were then examined and observed under light microscope $\mathrm{e}^{[20]}$.

\section{Morphometric study:}

From H\&E stained section $(x 40)$ the difference between cortex and medulla thickness was measured using Digimizer 4.3.2. Image analysis software (MedCalc Software bvba, Belgium), and from H\&E stained sections ( $x 400$ ); the number of glomeruli was counted from $x 400$ 
photomicrographs using Digimizer. The area percent of NF-kBp65 positive cells immune-stained sections ( $\mathrm{x} 400)$; was measured by using the NIH ImageJ (v1.50) program. For each mentioned stain measured parameter, five nonoverlapping fields/rat sections were examined (The total was 50 measurements /group) and photographed using color video camera (digital camera CH- 9435 DFC 290). The photographs were analyzed using Leica Qwin 500 (Imaging System, Cambridge, UK) within a frame area of $293.4288 \mu \mathrm{m} 2$. Morphometry was carried out at the Image Analysis Unit, Histology Department, Faculty of Medicine, Zagazig University.

\section{Statistical management:}

The collected data were coded and analyzed by computer using a data base software program, Statistical Package for Social Science version 19 (SPSS). For quantitative variables mean, standard deviation was computed. Independent t- test was used for quantitative normally distributed data for detection difference between two different groups and also Mann-Whitney was used for quantitative not normally distributed data for detection difference between two different groups and one-way anova was used for quantitative normally distributed data for detection difference between more than two different groups.

\section{RESULTS}

\section{Histological Results}

\section{A-Two-Day-Old Rats}

\section{Control Group:}

Light microscopic examination of H\&E stained sections of the renal cortices of the control group showed two well defined zones: the subcapsular nephrogenic zone and the juxtamedullary zone. The subcapsular nephrogenic zone contained immature forms of renal developmental stages. The juxtamedullary zone contained formed glomeruli surrounded by convoluted tubules. The medullary rays extended from the medulla to the capsule across the two previous zones (Fig. 1).

In the subcapsular nephrogenic zone, the ureteric buds (UBs) were observed as straight tubules ending with swollen ampullae. Spherical clusters of mesenchymal cells were observed at the lower sides of the UBs' ampullae. Immature forms of renal developmental stages; comma-shaped and S-shaped bodies were observed in the nephrogenic zone close to the capsule. Some hemispherical glomeruli, in the capillary loop stage, were seen in the deep part of the nephrogenic zone close to the UBs. These glomeruli were surrounded by columnar podocytes forming the visceral layer of Bowman's capsule and flat endothelial cells forming the parietal layer. The juxtamedullary zone contained more mature nephrons consisting of well-formed glomeruli surrounded by primitive convoluted tubules. Mitotic figures were seen in the undifferentiated nephron epithelium (Figs. 2, 3).

\section{Acrylamide-Treated Group:}

Light microscopic examination of H\&E stained sections of the renal cortices of acrylamide-treated, 2-day-old rats revealed degenerated glomeruli with lack of capillary tufts. Disarrangement of podocytes and thickening of the parietal layers of Bowman's capsules were also noticed in some glomeruli. Few glomeruli appeared normal. Moreover, the damage was evident in the primitive tubules. Emerged swelling of the epithelial cells of the tubules and detached cells from the basement membrane could be also detected (Fig. 4).

\section{Ginger-Protected Group:}

Light microscopic examination of H\&E stained sections of the renal cortices of ginger-protected, 2-dayold rats revealed wide areas of renal tissue more or less similar to the examined control sections. The subcapsular nephrogenic zone contained immature forms of renal developmental stages in the form of comma-shaped and S-shaped bodies. The juxtamedullary zone contained more mature nephrons consisting of formed glomeruli surrounded by primitive tubules (Fig. 5).

\section{B-Twenty-One-Day-Old Rats}

\section{Control Group:}

Examination of H\&E stained sections of the kidneys of the control rats showed normal histological structure of the renal cortex. Each renal corpuscle consisted of a tuft of glomerular capillaries surrounded by narrow Bowman's urinary space. The outer parietal layer of Bowman's capsule was formed of simple squamous epithelium. The podocytes of the visceral layer had pale nuclei and cytoplasm and invested the glomerular capillaries. Each proximal convoluted tubule was lined by a single layer of high cuboidal cells with eosinophilic, granular cytoplasm and had small, uneven lumen with apical brush border. Whereas, the distal convoluted tubules were lined by cuboidal cells with large apical vesicular nuclei and had wider lumina with no brush borders (Fig. 6).

\section{Acrylamide-Treated Group:}

Light microscopic examination of $\mathrm{H} \& \mathrm{E}$ stained sections of the kidneys of acrylamide-treated, 21-day-old rats revealed disturbed architecture of the renal cortex. Some renal corpuscles showed congested glomerular capillaries, mesangial hypercellularity and apparent widening of Bowman's spaces. Some renal tubules revealed vacuolations and darkly stained nuclei of their lining cells, and exfoliated cells into their lumina. Extensive interstitial cellular infiltration and hemorrhage, congested blood vessels and peritubular capillaries, and blood vessels with irregular disturbed muscle fibers were also detected (Figs 7-9).

\section{Ginger-Protected Group:}

Sections of ginger-protected rats exhibited nearly preserved renal cortical architecture showing apparently 
normal renal corpuscles with decreased glomerular congestion, intact parietal layers of Bowman's capsules and minimal widening of the urinary spaces. Preservation of the normal shape and lining of most tubules was also detected. However, few tubules revealed luminal debris, vacuolated cells and darkly stained nuclei (Fig. 10).

\section{Immunohistochemistry}

Anti-NF-k $\beta$ p65 immune-stained sections of the control kidneys of both age groups showed NF-k $\beta$ negative immunoreaction in the renal corpuscle and renal tubular epithelium (Fig. 11). Acrylamide-treated rats of both age groups exhibited strong positive NF- $\mathrm{k} \beta$ immunoreaction in the epithelial cells of the renal tubules and glomerular cells (Fig. 12), the positivity was stronger in the 21-day-old rats. Whereas, in the ginger-protected rats of both age groups, weak positive NF-k $\beta$ immunoreaction was detected in few numbers of cells of the glomeruli and renal tubules (Fig. 13).

\section{Morphometric and Statistical Results}

Acrylamide-treated groups at both ages showed a highly statistically significant decrease in the mean glomerular count and the mean thickness of the cortex and the medulla as compared to their control groups. Whereas, there was a significant increase in these parameters in ginger-protected versus acrylamide-treated groups in each age (Tables 1, 2; Bar chart with error bar 1-3).

A highly significant increase in the area percentage of renal NF-k $\beta$ protein expression was observed in acrylamide-treated groups in comparison to their controls. However, a significant decrease was detected in gingerprotected versus acrylamide-treated rats of each age group (Tables 1, 2; Bar chart with error bar 4).

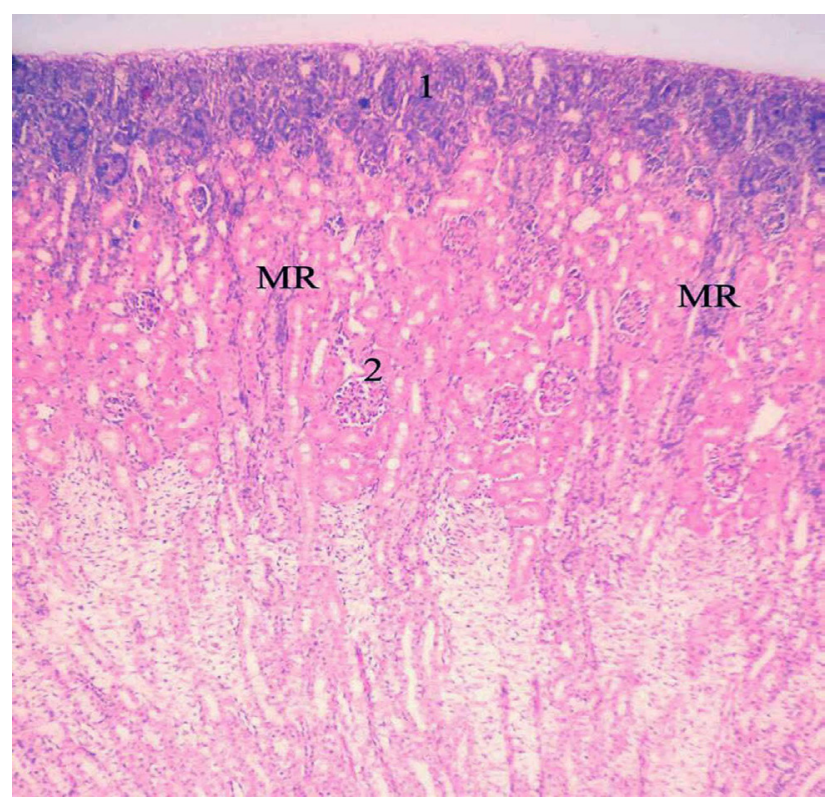

Fig. 1: A photomicrograph of a section in the renal cortex of a control, 2-day-old rat showing the subcapsular nephrogenic zone (1), the juxtamedullary zone (2) and the medullary rays (MR). H\&E.; X 100

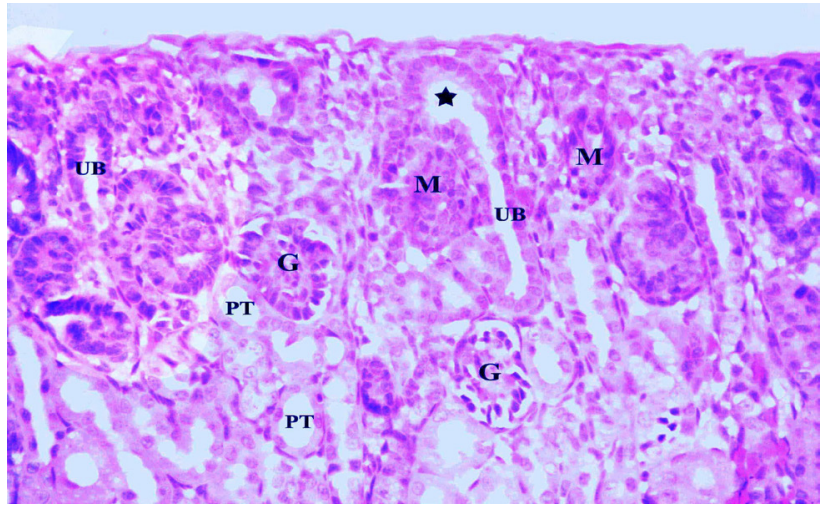

Fig. 2: A photomicrograph of a section in the renal cortex of a control, 2-day-old rat showing ureteric buds (UB) with dilated ampullae (star) Spherical clusters of mesenchymal cells (M) are observed at the sides of the UBs' ampullae. Some hemispherical glomeruli (G) and primitive tubules $(\mathrm{PT})$ are also seen.

H\&E.; X 400

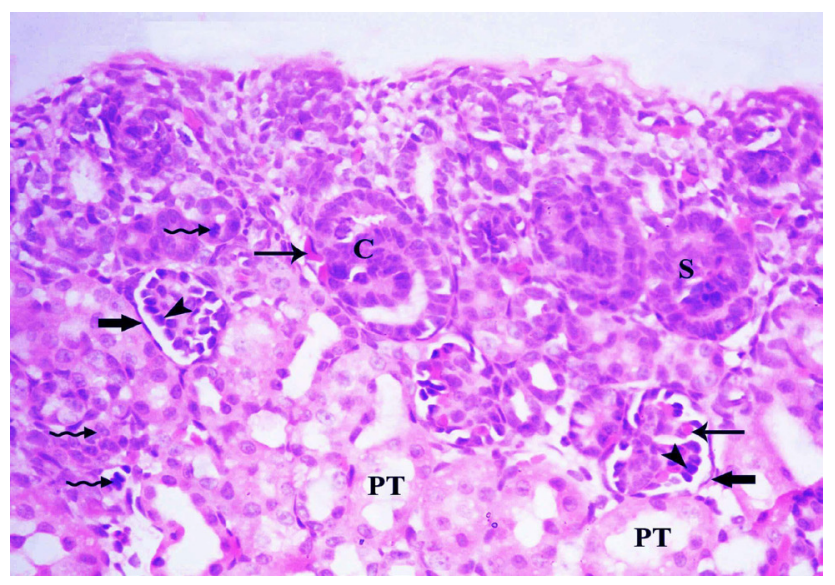

Fig. 3: A photomicrograph of a section in the renal cortex of a control, 2-day-old rat showing comma-shaped (C) and S-shaped (S) bodies close to the capsule. Formed glomeruli surrounded by visceral (arrow head) and parietal layers (thick arrow) of Bowman's capsule, few blood capillaries (thin arrow) and primitive tubules (PT) are observed. Mitotic figures (tailed arrow) are also detected.

H\&E.; X 400

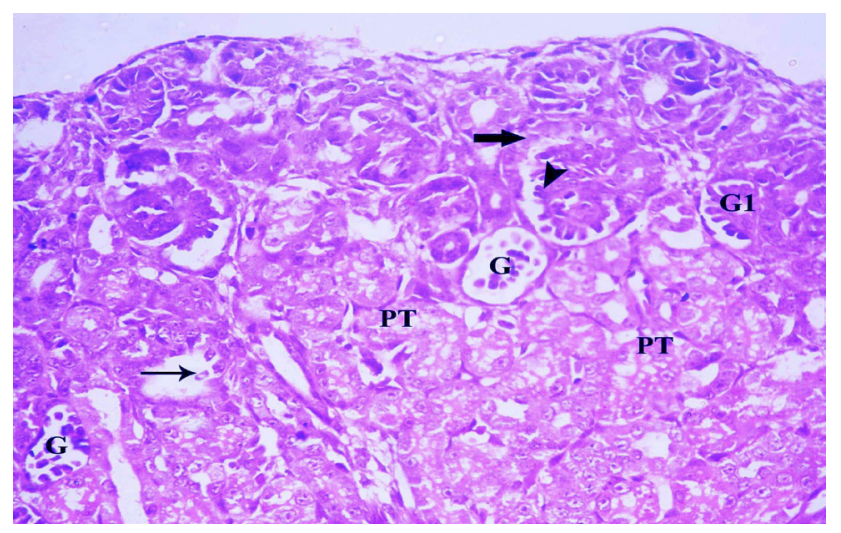

Fig. 4: A photomicrograph of a section in the renal cortex of an acrylamide-treated, 2-day-old rat showing degenerated glomeruli (G) with lack of capillary tufts. Disarrangement of podocytes (arrow head) and thickening of the parietal layer of Bowman's capsule (thick arrow) of another glomerulus are detected. Primitive tubules (PT) appear with highly vacuolated cytoplasm and exfoliated cells (thin arrow). Normal glomerulus (G1) with normally arranged podocytes is also observed. H\& E.; X 400 


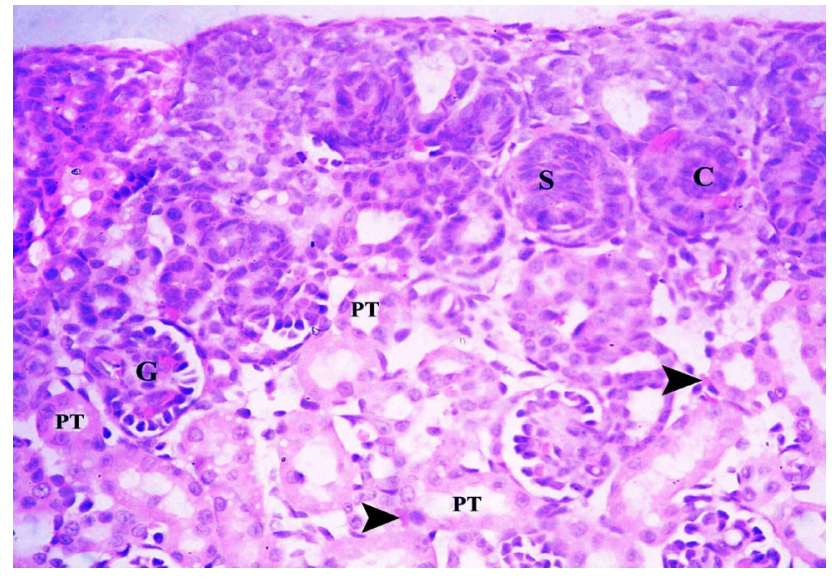

Fig. 5: A photomicrograph of a section in the renal cortex of a gingerprotected, 2-day-old rat showing comma-shaped (C) and S-shaped bodies (S) close to the capsule. The juxtamedullary zone contained more mature nephrons consisting of formed glomeruli $(G)$ surrounded by primitive tubules (PT). Peritubular congestion (arrow head) is seen. H\&E.; X 400

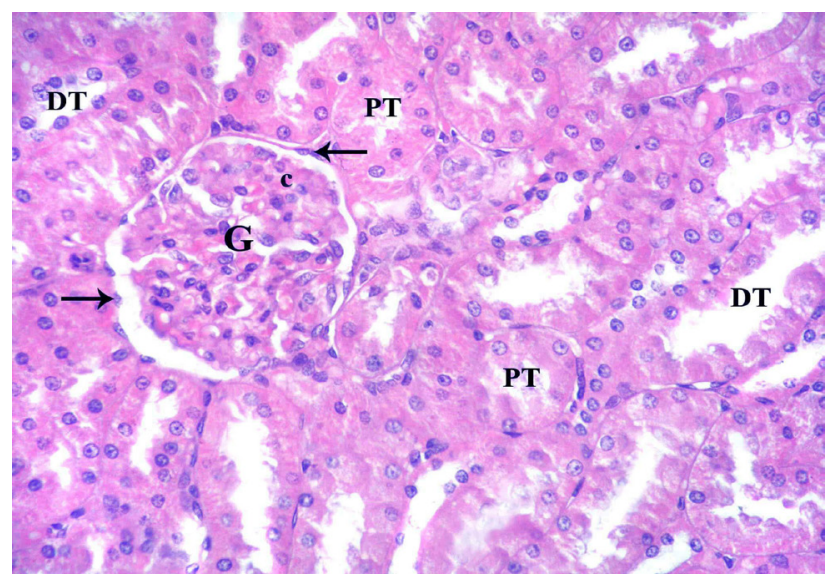

Fig. 6: A photomicrograph of a section in the renal cortex of a control, 21-day-old rat showing a glomerulus (G) with its capillaries (c) surrounded by normal Bowman's space (arrow). The proximal (PT) and distal convoluted tubules (DT) are also observed. $\quad$ H\&E.; X400

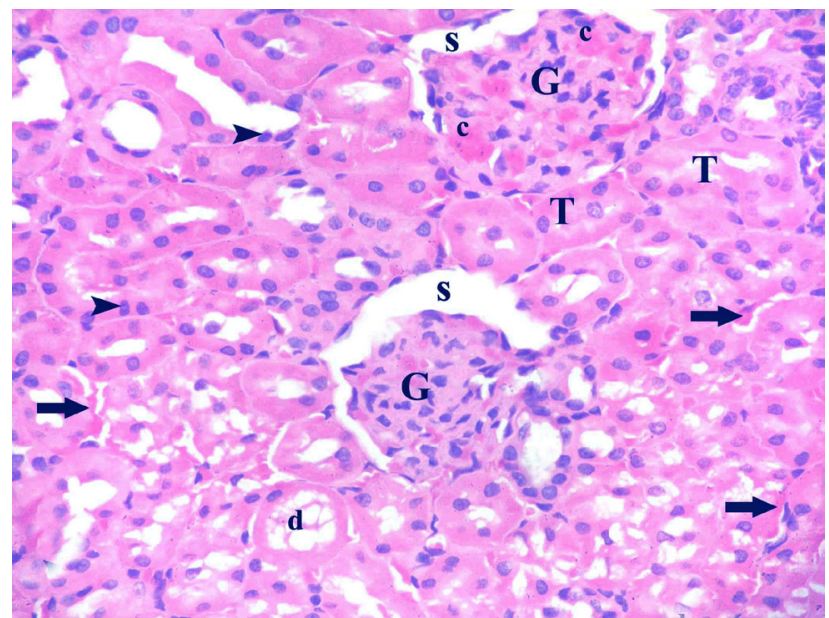

Fig. 7: A photomicrograph of a section in the renal cortex of an acrylamide-treated, 21-day-old rat showing irregular glomeruli $(\mathrm{G})$ with numerous congested capillaries (c), mesangial hypercellularity and wide Bowman's spaces (S). Tubules with luminal debris (d) and others with darkly stained nuclei (arrow head) can be seen. congested peritubular capillaries are also noticed.

H\&E.; X 400

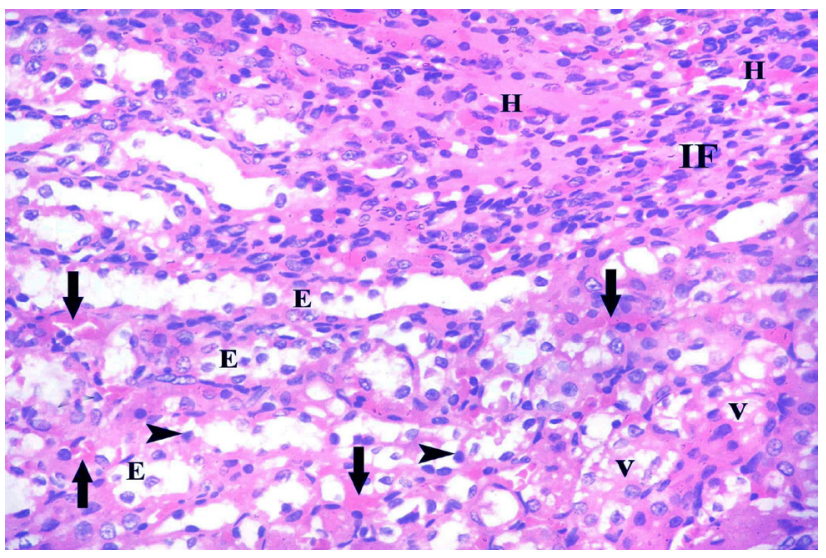

Fig. 8: A photomicrograph of a section in the renal cortex of an acrylamide-treated, 21-day-old rat showing extensive interstitial cellular infiltration (IF) and hemorrhage (H). Degenerated tubules with exfoliated cells (E), darkly stained nuclei (arrow head) and highly vacuolated cells (V) are seen. Numerous congested peritubular capillaries (arrow) are also noticed.

H\&E.; X400

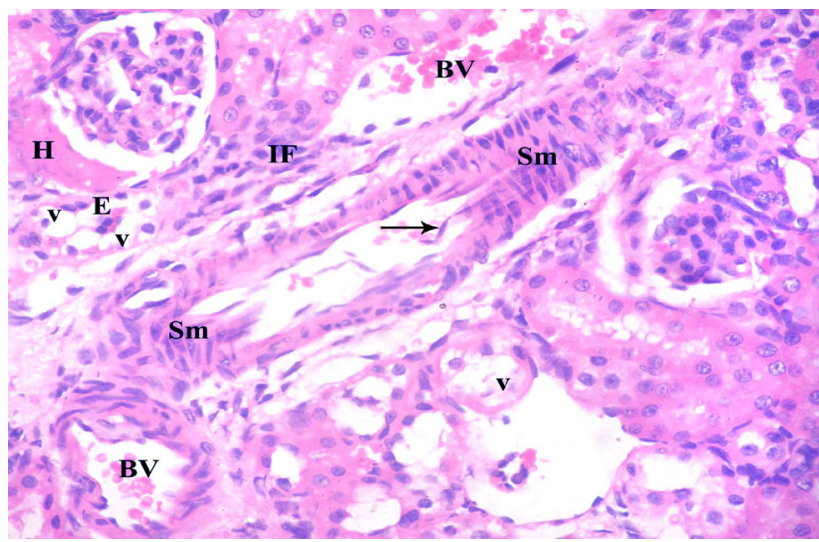

Fig. 9: A photomicrograph of a section in the renal cortex of an acrylamide-treated, 21-day-old rat showing congested blood vessels (BV). Another blood vessel has irregular disturbed muscle fibers (Sm) and spindle shaped endothelial lining (arrow). Interstitial cellular infiltration (IF), and distorted tubules with exfoliated (E) and vacuolated (V) cells are observed. Hyaline acidophilic material $(\mathrm{H})$ is also detected in a part of a glomerulus.

H\&E.; X 400

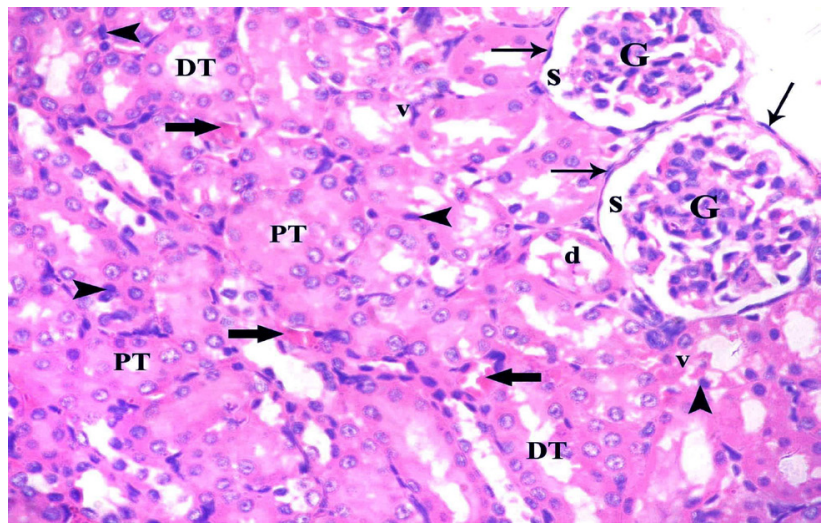

Fig. 10: A photomicrograph of a section in the renal cortex of a ginger-protected, 21-day-old rat showing intact parietal layers of Bowman's capsules (arrow) and minimal widening of the urinary spaces (S) surrounding 2 glomeruli (G). Normal proximal (PT) and distal convoluted tubules (DT) are observed. Few tubules with lumina debris (d), vacuolated cells (v) and darkly stained nuclei (arrow head) can be seen. Few blood capillaries (thick arrow) can be also observed. 

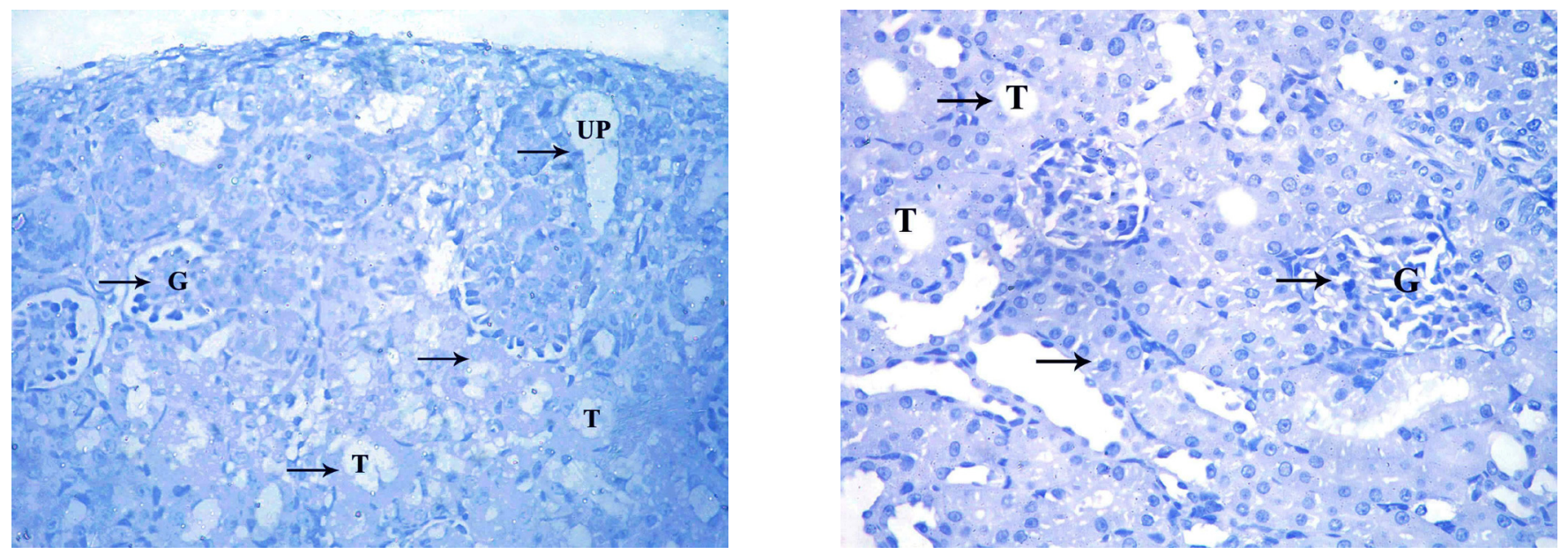

Fig. 11: A photomicrograph of Anti-NF-k $\beta$ p65 immune-stained sections of the renal cortices of the control group of the 2-day-old rats (A), 21-day-old rats (B) showing a negative immunoexpression (arrow) in the glomeruli $(\mathrm{G})$ and the epithelium of the renal tubules (T). NF-k $\beta$ p65 immunoperoxidase stain counter stained with H.; X400
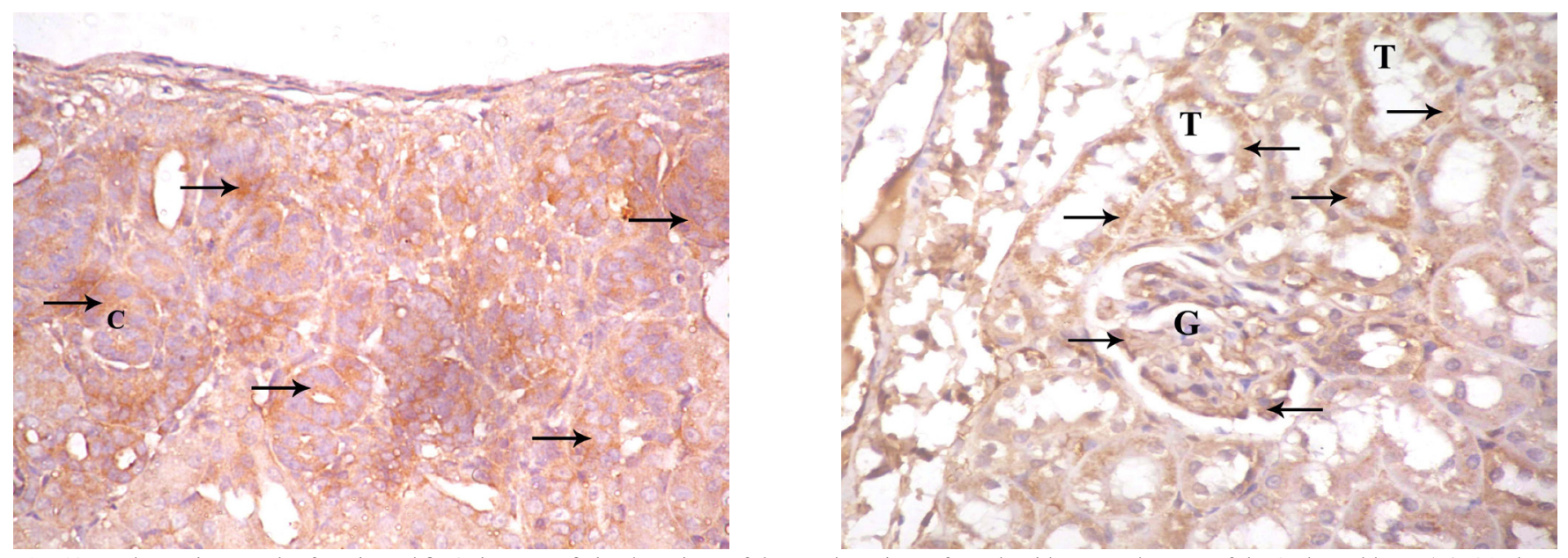

Fig. 12: A photomicrograph of Anti-NF-k $\beta$ p65 immune-stained sections of the renal cortices of acrylamide-treated group of the 2-day-old rats (A), 21-dayold rats (B) showing strong positive reaction (arrow) in the epithelial cells of the renal tubules (T) and the glomerular cells (G) in both age groups. NF-k $\beta$ p65 immunoperoxidase stain counter stained with H.; X400
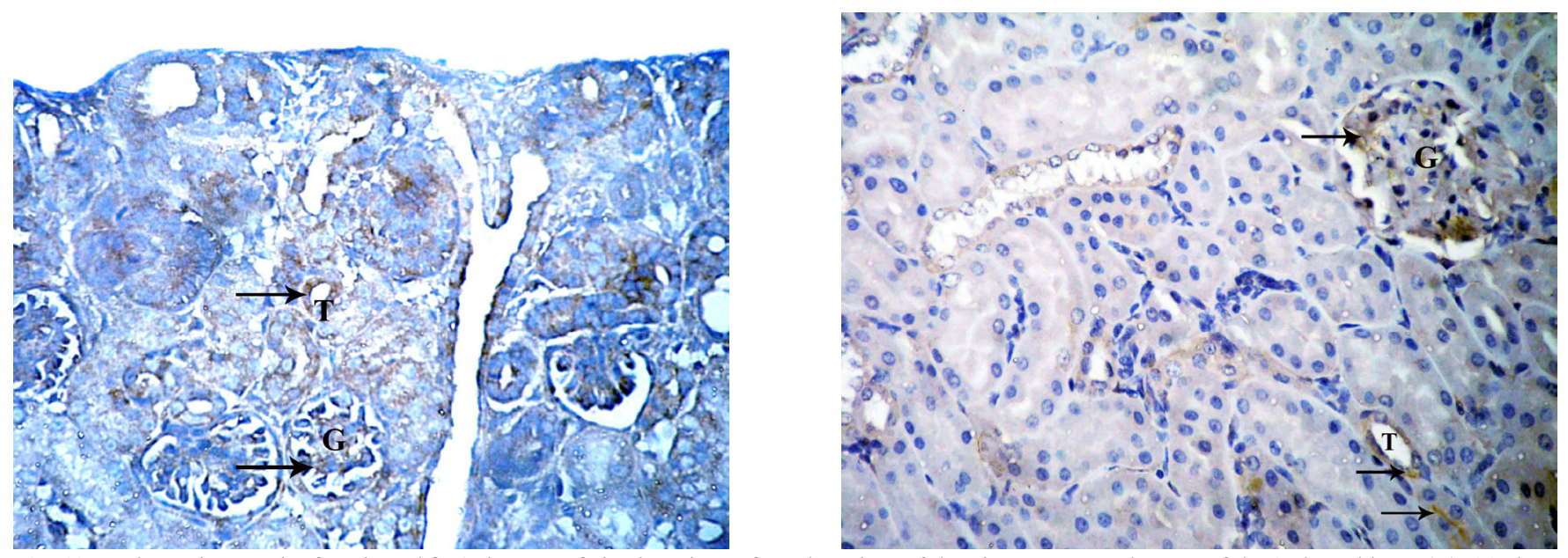

Fig. 13: A photomicrograph of Anti-NF-kßp65 immune-stained sections of renal cortices of the ginger-protected group of the 2-day-old rats (A), 21-dayold rats (B) showing faint positive reaction (arrow) in the epithelial cells of the renal tubules (T) and the glomerular cells (G) in both age groups. NF-k $\beta$ p65 immunoperoxidase stain counter stained with H.; X400. 
Table 1: Morphometric measurements of all studied groups in the 2nd day, using analysis of variance test

\begin{tabular}{|c|c|c|c|c|}
\hline \multirow{2}{*}{ Parameter } & \multicolumn{3}{|c|}{ 2-day-old rats } & \multirow{2}{*}{ P value } \\
\hline & Control group & Treated group & Protected group & \\
\hline Cort thickness $(\mu \mathrm{m})$ & & & & $P 1<0.001$ * \\
\hline Mean $\pm \mathrm{SD}$ & $449.81 \pm 59.47$ & $359.02 \pm 27.62$ & $445.55 \pm 23.74$ & $P 2<0.001 *$ \\
\hline \multirow[t]{2}{*}{ Range } & $(379.4-541.5)$ & $(311.6-390.1)$ & $(406.7-481.8)$ & P3 $\quad 0.825$ \\
\hline & & & & $P 4<0.001 *$ \\
\hline Med thickness $(\mu \mathrm{m})$ & & & & $P 1<0.001 *$ \\
\hline Mean \pm SD & $580.08 \pm 108.04$ & $344.4 \pm 87.05$ & $540.71 \pm 130.42$ & $P 2<0.001^{*}$ \\
\hline \multirow[t]{2}{*}{ Range } & $(463.7-730.9)$ & (166.6- 445.3) & $(326.9-709.50)$ & P3 $\quad 0.455$ \\
\hline & & & & $P 4<0.01 *$ \\
\hline NF-k $\beta$ expression & & & & $P 1<0.001^{*}$ \\
\hline Mean \pm SD & $1.30 \pm 0.55$ & $58.93 \pm 11.29$ & $17.41 \pm 14.73$ & $P 2<0.001^{*}$ \\
\hline \multirow[t]{2}{*}{ Range } & $(0.71-2.39)$ & $(43.76-75.89)$ & $(2.16-52.03)$ & P3 $0.004 *$ \\
\hline & & & & $P 4<0.001$ * \\
\hline Glomerular count & & & & $P 1<0.001 *$ \\
\hline Mean \pm SD & $16.55 \pm 3.0$ & $10.11 \pm 2.84$ & $16.33 \pm 1.58$ & $P 2<0.001 *$ \\
\hline \multirow[t]{2}{*}{ Range } & $(10-20)$ & $(6-15)$ & $(14-19)$ & P3 0.855 \\
\hline & & & & $P 4<0.001 *$ \\
\hline
\end{tabular}

Cort: cortical; Med: medullary; P1: P value of the three studied groups; P2: control group versus treated group; P3: control group versus protected group; P4 treated group versus protected group. $P>0.001$ is highly significant; $P>0.05$ is significant

Table 2: Morphometric measurements of all studied groups in the 21st day, using analysis of variance test

\begin{tabular}{|c|c|c|c|c|}
\hline \multirow{2}{*}{ Parameter } & \multicolumn{3}{|c|}{ 21-day-old rats } & \multirow{2}{*}{$P$ value } \\
\hline & Control group & Treated group & Protected group & \\
\hline Cort thickness $(\mu \mathrm{m})$ & & & & $P 1<0.001^{*}$ \\
\hline Mean \pm SD & $797.41 \pm 85.18$ & $614.32 \pm 27.72$ & $717.53 \pm 23.81$ & $P 2<0.001 *$ \\
\hline \multirow[t]{2}{*}{ Range } & $(729.98-967.7)$ & $(567.1-665.3)$ & $(674.3-747.2)$ & $P 3<0.004^{*}$ \\
\hline & & & & $P 4<0.001 *$ \\
\hline Med thickness $(\mu \mathrm{m})$ & & & & $P 1<0.001$ * \\
\hline Mean \pm SD & $1653.53 \pm 250.3$ & $890.91 \pm 183.84$ & $997.98 \pm 227.3$ & $P 2<0.001$ * \\
\hline \multirow[t]{2}{*}{ Range } & $(1210.2-1937.7)$ & $(592.0-1110.6)$ & $(507.5-1239.7)$ & $P 3<0.001$ * \\
\hline & & & & P4 0.317 \\
\hline NF-k $\beta$ expression & & & & $P 1<0.001 *$ \\
\hline Mean \pm SD & $4.47 \pm 7.04$ & $62.57 \pm 10.9$ & $22.28 \pm 13.67$ & $P 2<0.001 *$ \\
\hline \multirow[t]{2}{*}{ Range } & $(1.06-23.16)$ & $(47.33-78.57)$ & $(3.99-45.0)$ & P3 $0.002 *$ \\
\hline & & & & $P 4<0.001 *$ \\
\hline Glomerular count & & & & $P 1<0.001 *$ \\
\hline Mean \pm SD & $21.88 \pm 3.55$ & $15.0 \pm 1.93$ & $23.22 \pm 4.86$ & P2 $0.001^{*}$ \\
\hline \multirow[t]{2}{*}{ Range } & $(17-27)$ & $(12-18)$ & $(16-30)$ & P3 0.446 \\
\hline & & & & $P 4<0.001 *$ \\
\hline
\end{tabular}

Cort: cortical; Med: medullary; P1: P value of the three studied groups; P2: control group versus treated group; P3: control group versus protected group; P4 : treated group versus protected group.

$P>0.001$ is highly significant; $P>0.05$ is significant 


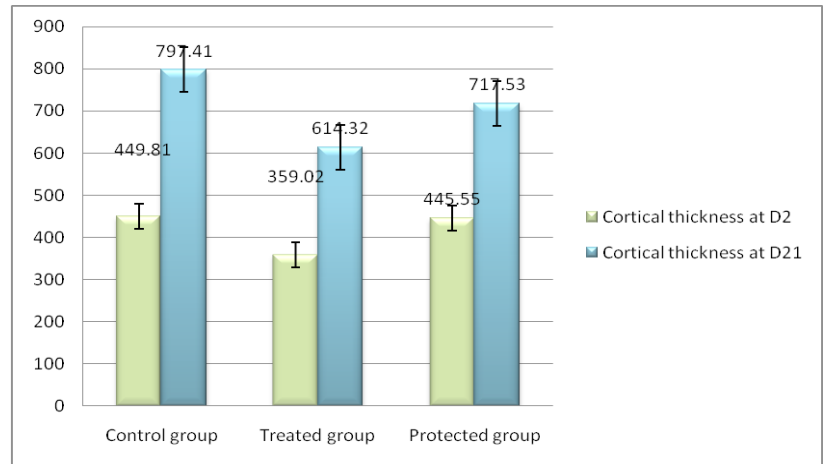

Bar chart with error bar 1: Mean \pm SD values of cortical thickness in all studied groups at the $2^{\text {nd }}$ and $21^{\text {st }}$ postnatal days.

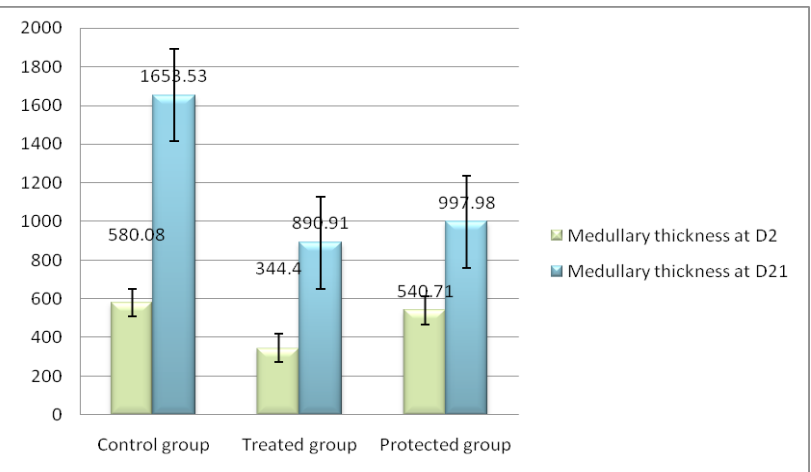

Bar chart with error bar 2: Mean \pm SD values of medullary thickness in all studied groups at the $2^{\text {nd }}$ and $21^{\text {st }}$ postnatal days.

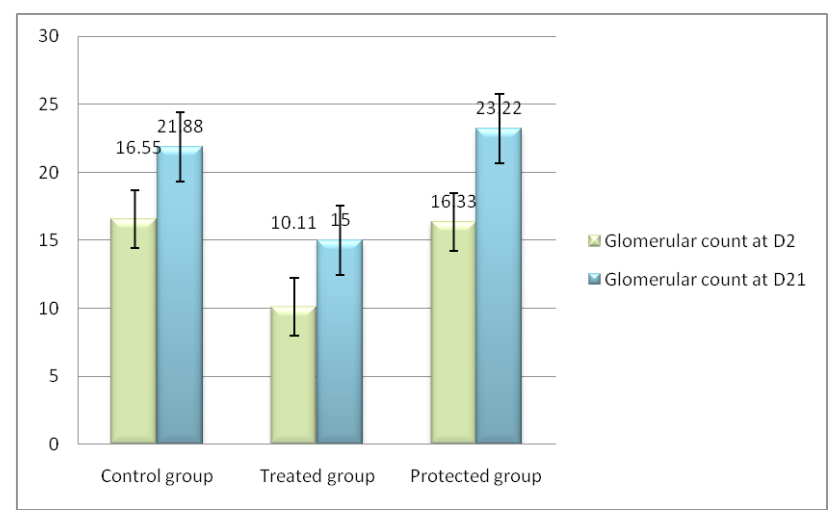

Bar chart with error bar 3: Mean \pm SD values of glomerular count in all studied groups at the $2^{\text {nd }}$ and $21^{\text {st }}$ postnatal days

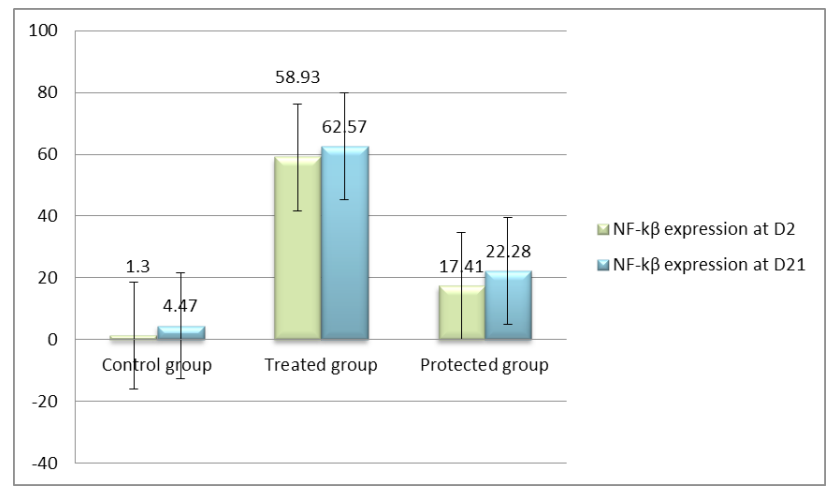

Bar chart with error bar 4: Mean \pm SD of the area percentage of renal $\mathrm{NF}-\mathrm{k} \beta$ protein expression in all studied groups at the $2^{\text {nd }}$ day and $21^{\text {st }}$ .postnatal days

\section{DISCUSSION}

Although multiple organs could be affected after a maternal perturbation, the kidney is particularly susceptible potentially due to the differences in the fetal renal hemodynamics and the inability to form new nephrons after birth $^{[21]}$.

In the current work, examination of the renal cortices of the control, two-day-old rats exhibited two welldefined zones: the subcapsular nephrogenic zone and the juxtamedullary zone. The subcapsular nephrogenic zone revealed immature forms of different renal developmental stages as well as ureteric buds (UBs) which appeared as straight tubules ending with swollen ampullae surrounded by mesenchymal cells. The juxtamedullary zone contained formed glomeruli surrounded by convoluted tubules. In agreement with the results of the present study, Suzuki ${ }^{[22]}$ described the postnatal morphological maturation as centrifugal, that is, maturation proceeds from the inner cortex toward the periphery. Moreover, Seely ${ }^{[23]}$ stated that the UBs induce condensation of the metanephric mesenchyme. The primitive epithelium forms small vesicles, which become reorganized to form commaand subsequent S-shaped bodies. As the S-shape body elongates, vasculogenesis begins as endothelial cells migrate into the distal end of the S-shaped body.

In the present study, the renal corpuscles of acrylamidetreated, two-day-old rats revealed degenerated glomeruli with lack of capillary tufts. Disarrangement of podocytes and activated parietal epithelial cells (PECs) were also noticed in some glomeruli. The failure of normal glomerular capillary loops development, depicted in the current study, could be attributed to the inability of mesangial cells to orient these loops because of their inability to securely attach to the glomerular basement membrane ${ }^{[24]}$. Moreover, Scott and Quaggin ${ }^{[25]}$ reported that vascular endothelial growth factor A (VEGFA), secreted by the podocytes in the $\mathrm{S}$-shaped bodies, is a potent chemotactic factor essential for vasculogenesis. Homogenous ablation of VEGFA from podocytes results in grossly abnormal glomeruli with dramatically fewer glomerular endothelial cells that rapidly degenerate.

Activated PECs, featured by their enlarged rounded nuclei and increased cuboidal cytoplasm, are directly involved in the pathogenesis of certain glomerular diseases. The precise role of activated PECs remains unclear; it might be potentially detrimental or beneficial in glomerular diseases. On one hand, the overgrown PECs could obstruct the urine flow and release chemokines and cytokines, which could impair the function of the affected glomeruli. On the other hand, PECs could migrate to the capillary tuft and differentiate into podocytes serving a reparative role when podocytes are $\operatorname{los}^{[26,27]}$.

In the present work, some renal corpuscles of acrylamide-treated, 21-day-old rats showed congested glomerular capillaries, mesangial hypercellularity and apparent widening of Bowman's spaces. Other corpuscles 
revealed collapsed glomerular tufts and glomerular crescents. In agreement with the results of the present study, Jmahidi ${ }^{[28]}$ reported that intraperitoneal administration of acute nephrotoxic doses of acrylamide (50 and $100 \mathrm{mg} /$ $\mathrm{kg}$ /day for 11 days) to Wistar rats resulted in glomerular hypercellularity and proliferative glomerulonephritis (GN). Furthermore, Mahmood et al. ${ }^{[2]}$ and Rajeh and AlDhaheri ${ }^{[29]}$ detected degenerated glomerular tufts and distended Bowman's capsules in rats treated by different doses of acrylamide. Puelles et al. ${ }^{[30]}$ demonstrated that reduction in the glomerular count leads to compensatory hypertrophy of the remaining glomeruli with time.

Glomerular crescents are defined as extracapillary proliferation of more than two cell layers of any size. The major pathologic event that causes crescent formation is rapture of the glomerular capillaries that allows cellular and humoral inflammatory mediators to spill into Bowman's space $^{[31]}$. Glomerular crescent formation is a feature of rapidly progressive $\mathrm{GN}$ and is associated with a poor prognosis. PECs present in the cellular crescents undergo epithelial-to-mesenchymal transition potentially due to the deposition of extracellular matrix proteins resulting in the development of fibrocellular crescents ${ }^{[32]}$. Activation of the nuclear factor kappa $\beta(\mathrm{NF}-\mathrm{k} \beta)$ play a crucial role in the pathogenesis of crescentic GN and activation of macrophages and $\mathrm{T}$ cells ${ }^{[33]}$.

In the current study, the damage was also evident in the renal tubules of acrylamide-treated rats at both age groups in terms of vacuolations and apoptotic nuclei of their lining cells, and exfoliated cells into their lumina. In agreement with the results of the present study, Özturan-Özer et $a l{ }^{[34]}$ detected dose-dependent alterations in the epithelial cells of the proximal tubules of acrylamide-treated rats in the form of vacuolization, swollen mitochondria and degenerated cells. These findings could be attributed to the fact that kidneys are the way of excretion of acrylamide and its metabolites.

The kidneys of acrylamide-treated, 21-day-old rats showed extensive interstitial cellular infiltration and hemorrhage as well as congested blood vessels and peritubular capillaries. These results are similar to those reported by El-Sayyad et al. ${ }^{[35]}$ and Rawi et al. ${ }^{[36]}$. Lee et $a l .{ }^{[37]}$ reported that, NF-k $\beta$ dependent pathways play an important role in macrophage infiltration and kidney injury. The present histological alterations of the renal cortical blood vessels in acrylamide-treated, 21-day-old rats are compatible with the finding of Huang et al..$^{[38]}$ that evidenced cardiovascular developmental toxicity of acrylamide in zebrafish embryos. Furthermore, Sellier et $a l .{ }^{[39]}$ demonstrated a dose- and time-dependent vascular toxicity of acrylamide and its metabolite glycidamide on human umbilical vein endothelial cells.

In the present work, the mean glomerular counts, indicative of the actual nephron numbers, were significantly decreased in acrylamide-treated rats of both age groups relative to their controls. In consistence with the current results, Mahmood et al. ${ }^{[2]}$ attributed chronic renal failure, detected in acrylamide-treated rats, to progressive and irreversible loss of nephrons. The authors added that clinical symptoms often do not occur until the number of the functioning nephrons falls to at least $70-75 \%$ below normal. Nephron number provides a quantitative index of the success of nephrogenesis during kidney development ${ }^{[40]}$. Nephron number is sensitive to fetal environmental perturbations $^{[41]}$. Loss of nephrons when nephrogenesis is still ongoing, may elicit different compensatory responses augmenting the risk of adult hypertension prior to any evidence of renal injury ${ }^{[42]}$.

In the current study, acrylamide-treated rats at both age groups showed highly statistically significant decreases in the mean thickness of the cortex and the medulla as compared to the control groups. Korkmaz et $a l .{ }^{[43]}$ suggested that cortical thickness is a good indicator for renal function impairment. Additionally, Beland et $a l .{ }^{[44]}$ stated that progressive decrease in the cortical thickness might be an early sign of renal failure. In most cases, chronic kidney disease leads to a common final stage characterized by cortical and parenchymal thinning indicating atrophy; such findings indicate poor prognosis and disease irreversibility ${ }^{[45]}$.

Nuclear factor kappa $\beta$ is a crucial transcription factor for the regulation of many physiological and pathological associated processes; it is closely associated with cancer development and plays a pivotal role in promotion of cell proliferation and inflammation ${ }^{[46]}$. NF- $\kappa \beta$ is involved in the control of the expression of a variety of cellular genes that regulate the inflammatory response by the production of chemokines, cytokines, acute phase proteins and cell adhesion molecules ${ }^{[26]}$. Over-activity of NF- $\kappa \beta$ also leads to altered gene expression of vascular endothelial growth factor (VEGF), platelet-derived growth factor (PDGF), endothelin-1, activated protein $\mathrm{C}$ and transforming growth factor- $\beta$ that ends into vascular cell damage ${ }^{[47]}$. In the present study, acrylamide treatment induced a highly significant increase in the renal NF-k $\beta$ protein expression, suggesting the involvement of NF-k $\beta$ in the pathogenesis of acrylamide-induced renal damage. The involvement of $\mathrm{NF}-\mathrm{k} \beta$ is especially of interest as it is activated by oxidative stress and its activation can be modulated by antioxidant compounds $^{[48]}$

On the other hand, the groups of rats simultaneously treated by ginger revealed preserved renal histological structure and morphometric measures. the renoprotection conferred by ginger is at least partly related to reduced $\mathrm{NF}-\mathrm{k} \beta$ activation. In consistence with the present results, Saberi et al. ${ }^{[49]}$ reported that ginger extract pretreatment protects against radiation-induced histological and biochemical changes in the rat kidney. Moreover, Al-Waili et $a l .{ }^{[50]}$ stated that ginger and its derivatives decrease inflammatory processes in diabetic nephropathy as well as increase antioxidants by affecting NF-k $\beta$ activation. The antioxidant action of ginger has been proposed as one of the major possible mechanisms for the protective actions 
against toxicity, in addition to strong anti-inflammatory and anti-apoptotic actions ${ }^{[51,52]}$

In conclusion, ginger administration effectively restored most of the acrylamide-induced renal cortical damage, suggesting that ginger supplement can play a protective role against acrylamide deleterious effects.

\section{REFERENCES}

1. Mannaa F, Abdel-Wahhab MA, Ahmed HH, Park MH. Protective role of Panax ginseng extract standardized with ginsenoside $\mathrm{Rg} 3$ against acrylamide-induced neurotoxicity in rats. J. Appl. Toxicol 2006; 26 (3): 198-206.

2. Mahmood SA, Amin KA, Salih, SF. Effect of acrylamide on liver and kidneys in albino wistar rats. International Journal of Current Microbiology and Applied Science 2015; 4:434-444.

3. Friedman M. Chemistry, biochemistry, and safety of acrylamide- A review. J Agricult Food Chem 2003; 51:4504-26.

4. Exon JH. A review of the toxicology of acrylamide, J. Toxicol. Environ. Health B Crit. Rev 2006; 9: $397-412$

5. Nojska H, Gielecińska I, Marecka D, Kłys W. Study of the influence of raw material and processing conditions on acrylamide level in fried potato chips. Rocz Panstw Zakl Hig 2008; 59 (2): $163-172$.

6. Parzefall W. Minireview on the toxicity of dietary acrylamide, Food Chem. Toxicol 2008; 46: 13601364.

7. Abd El Motelb EM, Rashad AY. Some studies on acrylamide intoxication in male albino rats. Egypt. J. Comp. Path. \& Clinic. Path 2008; 21 (4):222 245 .

8. Friedman M, Levin CE. Review of methods for the reduction of dietary content and toxicity of acrylamide. J. Agric. Food Chem 2008; 56 (15):6113-40.

9. Mahmood SA, Amin K, Rahman HS, Othman HH. The Pathophysiological effects of acrylamide in albino wister rats. International Journal of Medical Research \& Health Sciences 2016; 5 (7):42-48.

10. Yilmaz B, Yildizbayrak N, Aydin Y, Erkan M. Evidence of acrylamide- and glycidamide-induced oxidative stress and apoptosis in Leydig and Sertoli cells. Human and Experimental Toxicology 2017; 36 (12): 1225-1235.

11. Seale SM, Feng Q, Agarwal AK, El-Alfy AT. Neurobehavioral and transcriptional effects of acrylamide in juvenile rats. Pharmacol. Biochem. Behav 2012; 101:77 84.
12. Ma Y, Shi J, Zheng M, Liu J, Tian S, He X, Zhang D, Li G, Zhu J. Toxicological effects of acrylamide on the reproductive system of weaning male rats. Toxicol. Ind. Health 2011; 27 (7): 617-627.

13. Hogervorst JG, Baars BJ, Schouten LJ, Konings EJ, Goldbohm RA, van den Brandt PA. The carcinogenicity of dietary acrylamide intake: a comparative discussion of epidemiological and experimental animal research, Crit Rev. Toxicol 2010; 40 (6):485-512.

14. Dortaj H, Anvairi M, Yadegari M, Sharifabad H. Stereological Survey of the Effect of Vitamin $\mathrm{C}$ on Neonatal Rat KidneyTissue Treated With Acrylamide Sarcheshmeh AA. Mod Med Lab J 2017; 1(2): 42-49.

15. Sumner SCJ, Selvaraj L, Nauhaus SK, Fennell TR. Urinary metabolites from F344 rats and B6C3F1 mice coadministered acrylamide and acrylonitrile for 1 or 5 days. Chem. Res. Toxicol 1997; 10:115260 .

16. Atef H, Atteia GM, Rezk HM, El Shafey M. Effect of vitamin $\mathrm{E}$ on biochemical ultrastructural changes in acrylamide induced renal toxicity in rats. International Journal of Science Reports 2017 ; 3 (5):134-143.

17. Sakr SA, Lamfon HA, Essawy AE. Ginger (Zingiber officinale) extract ameliorates metalaxyl fungicide induced nephrotoxicity in albino mice. African Journal of Pharmacy and Pharmacology 2011; 5: 104-112.

18. Johari H, Delirnasa FB, Sharifi E, Hemayat-Khah V, Pourdanesh M. The Effects of Hydro-Alcoholic Extract of Zingiber Officinale on Prevention from Plumbism in Kidney Tissue of Neonatal Rats. Zahedan J. Res. Med. Sci 2013; 15 (8): 13-17.

19. Zamani N, Hosseini E, Modaresi M, Pirbalouti AG. Investigating the prenatal exposure of hydroalcoholic extract of ginger on the function of Pituitary - Gonad axis in male mature offspring rats. Journal of family medicine 2017; 15: 141148 .

20. Banchroft JD, Stevens A, Turner DR. Theory and practice of histological techniques. Fourth Ed. Churchil Livingstone, New York, London, San Francisco, Tokyo 1996; 4: 25-60.

21. Moritz KM. The effect of the in utero environment on nephrogenesis and renal function. In Kidney development, disease, repair and regeneration. Edited by Little, M.H., Elsevier Inc 2016; 177-186.

22. Suzuki M. Children's toxicology from bench to bed -Drug-induced renal injury (4): Effects of nephrotoxic compounds on fetal and developing kidney. Journal of Toxicological Sciences 2009; 34 (2): 267-271. 
23. Seely JC. A brief review of kidney development, maturation, developmental abnormalities, and drug toxicity: Juvenile animal relevancy. Journal of Toxicologic Pathology 2017; 30(2):125-133.

24. Kikkawa Y, Virtanen I, Miner JH. Mesangial cells organize the glomerular capillaries by adhering to the $\mathrm{G}$ domain of laminin alpha5 in the glomerular basement membrane. Journal of Cell Biology 2003 ; 161:187-196.

25. Scott RP, Quaggin SE. Formation and maintenance of a functional glomerulus. In Kidney development, disease, repair and regeneration. Edited by Little, M.H., Elsevier Inc 2016; 103-114.

26. Zhang H, Sun S. NF- $\mathrm{BB}$ in inflammation and renal diseases. Cell Bioscience 2015; 5:63.

27. Zhou W, Hildebrandt F. Inducible podocyte injury and proteinuria in transgenic zebrafish. Journal of the American Society of Nephrology 2012; 23(6): 1039-1047.

28. 28-Jmahidi K. Acrylamide - induced acute nephrotoxicity in rats. International Journal of Scientific Research in Science and Technology 2015; 1(5): 286-293.

29. Rajeh NA, Al-Dhaheri NM. Antioxidant effect of vitamin $\mathrm{E}$ and 5-aminosalicylic acid on acrylamide induced kidney injury in rats. Saudi Medical Journal 2017; 38(2):132-137 doi:10.15537/ smj.2017.2.16049.

30. Puelles VG, Douglas-Denton RN, Zimanyi MA, Armitage JA, Hughson MD, Kerr, PG, Bertram JF. Glomerular hypertrophy in subjects with low nephron number: contributions of sex, body size and race. Nephrology Dialysis Transplantation 2014; 29 (9): 1686-1695.

31. Jennette JC, Thomas DB. Crescentic glomerulonephritis. Nephrology Dialysis Transplantation 2001; 16 (8): 80-82.

32. Su H, Chen S, He F, Wang Y, Bondzie P, Zhang C. 2015.New insights into glomerular parietal epithelial cell activation and its signaling pathways in glomerular diseases. BioMed Research International 2015; 2015.

33. Sakai N, Wada T, Furuichi K, Iwata Y, Yoshimoto K, Kitagawa K, Kokubo S, et al. p38 MAPK phosphorylation and NF-KB activation in human crescentic glomerulonephritis. Nephrology Dialysis Transplantation 2002; 17: 998-1004.

34. Özturan-Özer E, Uçar G, Helvacıoğlu F, AkaydinAldemir D, Türkoğlu S. Effect of acrylamide treatment on arginase activities and nitric oxide levels in rat liver and kidney. Acta Medica Mediterranea 2014; 30: 375-382.
35. El-Sayyad HI, Abou-Egl MH, El-Sayyad FI Effects of fried potato chip supplementation on mouse pregnancy and fetal development. Nutrition 2011; 27: 343-350.

36. Rawi SM, Marie MA, Fahmy SR, El-Abied SR. Hazardous effects of acrylamide on immature male and female rats. African Journal of Pharmacy and Pharmacology 2012; 6 (18): 1367-1386.

37. Lee FTH, Cao Z, Long DM, Panagiotopoulos S, Jerums G, Cooper ME, Forbes J.M. Interactions between Angiotensin II and NF-k $\beta$-Dependent Pathways in Modulating Macrophage Infiltration in Experimental Diabetic Nephropathy. Journal of the American Society of Nephrology 2004; $15: 2139-2151$

38. Huang M, Jiao J, Wang J, Xia Z, Zhang Y. Characterization of acrylamide-induced oxidative stress and cardiovascular toxicity in zebrafish embryos. Journal of Hazardous Materials 2018; 347: 451-460.

39. Sellier C, Boulanger E. Maladry, F.; Tessier. F.J.; Lorenzi R.; Neviere, R.; Desreumaux, P.; Beuscart, J.; Puisieux, F. and Grossin, N.: Acrylamide induces accelerated endothelial aging in a human cell model. Food and Chemical Toxicology 2015; 83:140-145.

40. Bennette KM, Bertram JF, Beeman SC, Gretz N. The emerging role of MRI in quantitative renal glomerular morphology. American Journal of Physiology—renal Physiology 2013; 304 (10): 1252-1257.

41. Short KM, Smyth IM. The contribution of branching morphogenesis to kidney development and disease. Nature Reviews Nephrology 2016; 12: $754-767$.

42. Luyckx VA, Shukha K, Brenner BM. Low nephron number and its clinical consequences. Rambam Maimonides Medical Journal 2011; 2 (4).

43. Korkmaz M, Aras B, Güneyli S, Yılmaz M. Clinical significance of renal cortical thickness in patients with chronic kidney disease. Ultrasonography 2018; 37:50-54.

44. Beland MD, Walle NL, Machan JT, Cronan JJ. Renal cortical thickness measured at ultrasound: is it better than renal length as an indicator of renal function in chronic kidney disease? American Journal of Roentgenology 2010; 195: 146-149.

45. Kariyanna SS, Light RP, Agarwal RA. Longitudinal study of kidney structure and function in adults. Nephrology Dialysis Transplantation 2010; 25:1120-1126. 
46. Shen HM, Tergaonkar V. NFkappaB signaling in carcinogenesis and as a potential molecular target for cancer therapy. Apoptosis 2009; 14:348-363.

47. Suryavanshi SV, Kulkarni YA. NF- $\kappa \beta$ : A potential target in the management of vascular complications of diabetes. Frontiers in Pharmacology 2017; 8: 798.

48. van den Berg R, Haenen GR, van den Berg H, Bast A. Transcription factor NF-kappaB as a potential biomarker for oxidative stress. British journal of nutrition 2001; 86(1): S121-127.

49. Saberi H, Keshavarzi B, Shirpoor A, Gharalari FH, Rasmi Y. Rescue effects of ginger extract on dose dependent radiation-induced histological and biochemical changes in the kidneys of male Wistar rats.Biomedicine and Pharmacotherapy Oct 2017; 94:569-576.
50. Al-Waili N, Al-Waili H, Al-Waili T, Salom K Natural antioxidants in the treatment and prevention of diabetic nephropathy; a potential approach that warrants clinical trials. Redox Report 2017; 22 (3): 99-118.

51. Kim JK, Kim Y, Na KM, Surh YJ, Kim TY. [6]-Gingerol prevents UVB-induced ROS production and COX-2 expression in vitro and in vivo. Free Radical Research 2007; 41: 603-614.

52. Ali BH, Blunden G, Tanira MO, Nemmar A.Some phytochemical, pharmacological and toxicological properties of ginger (Zingiber officinale Roscoe): A review of recent research. Food and Chemical Toxicology 2008 ; 46 (2): 409-420. 


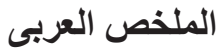

\title{
تأثثير مادة الأكريلاميد على القشرة الكلوية للجرذان بعد الولادة و التأثثر الوقائى للزنجبيل
}

\author{
رانيا سعيد معوض، ايمان رمضان عبد الفتاح، رانيا سعد رمضان \\ قسم التشريح والأجنة ـ كلية الطب ـ جامعة الزقازيق
}

وفقا للوكالة الدولية لبحوث السرطان ، تعثبر مادة الأكريلاميد مسببة للسرطان على أساس سرطنتها في القوارض كما تسبب تسمم في الحيو انات التجريبية و البشر. النباتات الطبية لها دور مهم في علم الصيدلة و الطب لسنوات عديدة. يحتوي الزنجبيل على أعلى كمية من مضادات الأكسدة، يهدف البحث الي تقييم التأثيرات النسيجية للأكريلاميد على كلى الجرذان بعد الو لادة وتحديد تأثثر الزنجبيل كمضاد للأكسدة. قسمت الفئران التجريبية بشكل عثوائي إلى ثلاث

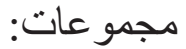

المجمو عة الاولي( المجمو عة الضابطة ) :تم الحفاظ على هذه الفئر ان في ظل ظروف طبيعية من النظام الغذائي و المباه. المجمو عة الثانية ( مجمو عة الاكريلاميد): تمت إذابة مادة الأكريلاميد في ماء مقطر ونم إعطاؤها عن طريق الفم إلى هي الفئر ان الحوامل غير المخدرة عن طريق التنبيب المعدي بجرعة 10 ميلي غر ام لكل كيلو غرام في اليوم. المجموعة الثالثة (مجموعة الاكريلاميد + الزنجبيل) : أعطيث الحيوانات في هذه المجموعة نفس جر عة الأكريلاميد الممنوحة لحيو انات المجمو عة الثانية يليها 1 مل من مستخلص نبات الزنجبيل (24 مجم / مل) ثلاث مر ات أسبو عيا لمدة 5 أسابيع. تم تطبيق هذه الجرعات من اليوم السابع من الحمل واستمرت حتى 21 يومًا بعد الولادة. تم اختيار الاعمار (الثاني و 21 يومًا بعد الو لادة) من كل مجموعة كما تم تجهيز قطاعات من الكلية وصباغتها بالهيماتوكسيلين والايوسين لفحص التغير ات الهستوباثولوجية بها. تم إجر اء التحليل الإحصائي لتقييم تأثثر مادة الأكريلاميد على قثرة الكلى الثابة بعد الو لادة. أظهر الفحص المجهري الخفيف للقشور الكلوية في اليوم الثاني في المجموعات الضابطة، ثلاث مناطق محددة بشكل جيد.. لوحظ في مجمو عة الأكريلاميد كبيبات منحلة و مناطق و اسعة من النسيج الكلوي أما في مجموعة الزنجبيل فهي تشبه الي حد كبير المجموعة الضابطة. أظهرت المجموعة الضابطة من الفئران البالغة من العمر 21 يوما البنية النسيجية الطبيعية للقشرة الكلوية بينما في المجمو عات المعالجة بالأكريلاميد كانت هنالك بنية مضطربة للقترة الكلوية. في الجرذان المحميّة بالزنجبيل في نفس اليوم تم الحفاظ على بنية القترة الكلوية. أظهرت الأجز اء الملطّخة بالمناعة من الكليتين الخاصتين بالعمر لكلتا الفئتين العمريتين سلبيّة NF-kß السلبية. بينما في الفئران المعالجة بالأكريلاميد من كلتا المجمو عتين العمريتين أظهرت إيجابية قوية NF-kß immunoreaction و إيجابية ضعيفة في مجمو عات معالجة الزنجبيل في كلا اليومين. كما يتم تحليل هذه النتائج إحصائياً وثبت أنها مهمة. و اظهرت الدراسة انه من الضروري تقييم التأثير ات النسيجية للأكريلاميد على كلى الجرذان بعد الو لادة ولتحديد نأثير الزنجبيل كمضاد للأكسدة. 